\title{
Colony integration and reproductive conflict in honey bees
}

\author{
P.K. Visscher \\ Department of Entomology, University of California, Riverside, CA 92521, USA
}

(Received 14 August 1997; accepted 14 November 1997)

\begin{abstract}
Honey bee colonies, although highly cooperative, are composed of genetically distinct individuals with differing genetic payoffs from alternative allocations of colony resources among potential reproductive individuals. Therefore conflicts among colony members are expected. This paper analyzes the empirical evidence of these conflicts in sex ratio, nepotism in queen rearing, and worker production of males. Sex ratio conflict is expected to be minimal and hard to measure in honey bees, but behavioral studies might provide insights. Nepotism in queen rearing has been investigated by several studies. The weight of the evidence suggests that weak nepotism does occur. This paper provides a reanalysis of the data of one controversial study and compares the methods and results of others. Mixed negative and positive findings may be due to certain methodological differences, or to polymorphism for this trait. Worker laying is much more common than has long been thought, but nonetheless nearly all adult drones derive from the queen, because worker policing removes nearly all worker-laid eggs. Policing, both of eggs laid and worker ovary development, also may be responsible for complete sterility of most workers. Thus reproductive cooperation in honey bees is underlain by a low level of active conflict. (C) Inra/DIB/AGIB/Elsevier, Paris
\end{abstract}

kin recognition / nepotism / worker laying / social behavior / Apis mellifera

\section{INTRODUCTION}

Honey bees, the best studied social insect species, can provide us with important insights into the balance of cooperation and conflict in evolution of social behavior. Their colonies show a remark- able degree of group level coordination, and honey bee colonies have long been characterized as paragons of cooperation. Pliny idealized the bees' organization as an example and lesson to human society (Fraser, 1951); Butler (1609) used the example of the bees to show the divine

\footnotetext{
* Correspondence and reprints
}

Tel.: (1) 909787 3973; fax: (1) 909787 3086; e-mail: visscher@citrus.ucr.edu 
ordainment of a society, like his own Elizabethan England, ruled by a queen; and from Thorley's (1774) day to this bees have been favored by pamphleteers as "arguments deduced from Nature (which) do demonstrate the being and perfections of God."

More recently, social insect colonies have been accorded special regard in evolutionary theory. Darwin (1859) saw social insect workers essentially as extensions of the phenotype of the reproductive individuals in a colony. This same view of the colony as an integrated phenotype gave rise to the superorganism view of insect societies (Wheeler, 1911), which was the dominant conception of insect societies for the first half of this century. What was not apparent to Darwin because he lacked knowledge of genetic mechanisms, and what was for many years underemphasized in the study of social insects, is that the colony is not a clone, but a collection of genetically distinct individuals, with correspondingly distinct genetic payoffs from their common enterprise.

Genetic payoffs come in reproduction, and in a honey bee society, propagation of the genes that reside in the individual colony members can take two paths: production of male reproductives (drones) and female reproductives (new queens).
To a large extent, the story of social life in honey bees is the story of maximizing the total of this reproduction through cooperation. Thus we find adaptations for cooperative foraging such as the dance language (von Frisch, 1967) and individually suicidal colony defense by stings, as well as specializations of the queen for laying eggs and workers for rearing her offspring, instead of their own.

However, since the bees in a colony are not genetically identical, different ways of allocating the colony's resources to production of drones and new queens can have different fitness consequences for various individuals in the colony. Figure 1 provides a framework for considering these differences in genetic payoff. In the production of reproductives, the colony faces various alternatives: what number of female and male reproductives to produce (central arrow in figure 1), which of the eggs fertilized with the sperm of the queen's many mates to rear as queens (left arrow) and which individuals' unfertilized eggs to rear into drones (right arrow). These alternatives are potential conflicts in the honey bee society, because different individuals in the colony will have different optimal allocations along these three axes, depending on their genetic relationships to the reproductives reared.

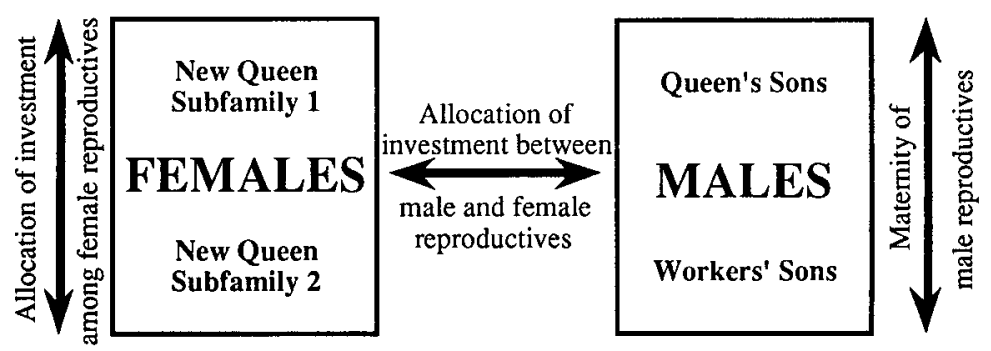

Figure 1. Axes of conflict in honey bee colonies. The arrows identify alternative ways in which the colony's resources could be allocated among potential reproductives, and represent conflicts because different individuals in the colony are expected to have different genetic payoffs for these alternatives. 
Figure 2 shows genetic structure of honey bee colonies and the genetic relationships between the potential reproductives in a colony. Honey bees are highly polyandrous, with a queen mating many times early in her life [Adams et al. (1977) estimated 7-17 matings] and then using semen from these matings in a largelybut-not-completely mixed fashion (Taber, 1955; Page and Metcalf, 1982; Page, 1986), so that a colony consists of many subfamilies of workers who share a father within subfamilies, but not between subfamilies. This paper is devoted to the question of whether the theoretical axes of conflict in reproduction identified in figure 1 are specifically reflected in the social behavior of honey bees, and what the consequence of these conflicts is in terms of the evolution of cooperative behavior.

The issues raised here are applicable to a wide range of social species, including social insects, birds, mammals, spiders, and other invertebrates, and the integra- tion of our understanding of the common forces shaping evolution of social behavior is a notable achievement of evolutionary biology over the last 25 years. However, I have restricted this paper to an in-depth analysis of the evidence concerning reproductive competition in just the best studied species: the honey bee Apis mellifera.

\section{CONFLICTS OVER SEX RATIO}

Trivers and Hare (1976), building on Fisher's (1958) sex ratio investment theory, pointed out that in colonies of singly mated social Hymenoptera, queens are related equally to their male and female reproductive offspring (and so would be expected to favor equal investment in each sex), but workers are more closely related to their sisters than to their brothers (and so would gain from greater investment in female reproductives). These relationships

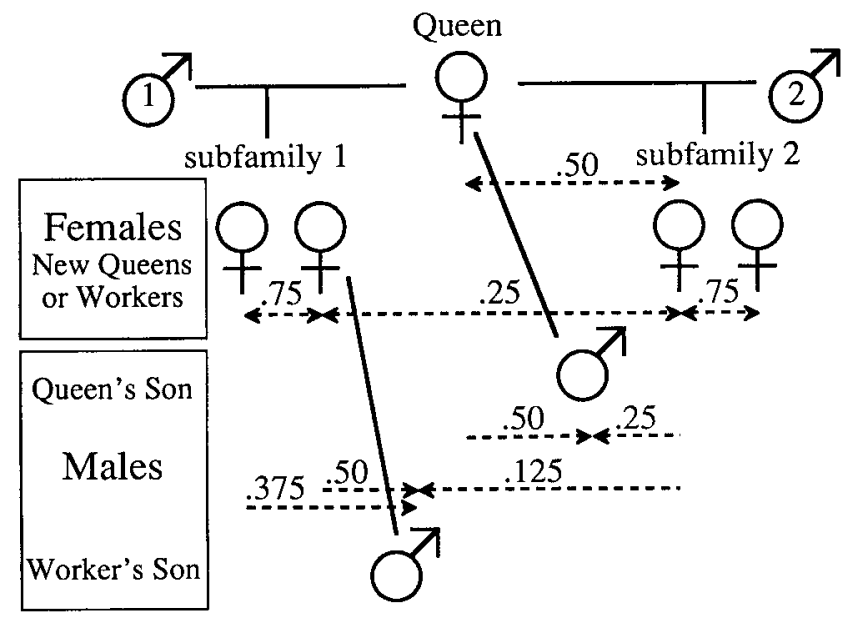

Figure 2. The genetic structure of honey bee families. The queen normally mates with many males, only two are shown here. The dashed lines indicate coefficients of relatedness between individuals (i.e. $G_{A B}$, the probability that a gene present in some individual $A$ will be present in another individual $\mathrm{B}$ by common descent). These coefficients can be asymmetric in Hymenoptera, and are shown only for female to male; each male's coefficients of relationship to other individuals are the same as his mother's. 
are shown in figure 2, if just one subfamily is considered. Evaluating the predictions of this theory provided one of the first ways of testing genetic theories of the evolution of sociality in Hymenoptera, and has stimulated a great deal of research on sex ratio allocation in ants. In honey bees, however, sex ratio conflict has received little attention, because less conflict is expected, and swarming reproduction makes investment in the two sexes much more difficult to measure.

In Hymenoptera, the relatedness between the workers and the queen's male offspring is 0.25 . Between the workers and the queen's female offspring, relatedness averages $0.25+0.5 / N$ where $N$ is the effective number of males whose semen is in use at a given time. When $N$ is high, the workers' are related to the queen's male and female offspring by similar coefficients, so there is less basis for sex ratio conflict, though some worker bias toward females would still be expected (assuming workers do not produce many of the males, an issue covered later in this paper).

The numerical sex ratio in honey bees is very strongly biased toward males: colonies will produce hundreds of times more drones than new queens (Seeley, 1985; Visscher, 1989). However, the investment in a new queen is very large, since the old queen will leave in a swarm with many of the workers in the colony, and a new queen may inherit the established nest, food stores and developing brood. Or she may leave with an afterswarm, or be killed by a rival new queen. The large and variable investments involved here make the ratio of total investment in drones and new queens challenging to calculate.

While the uncertainties of calculation of investment sex ratios in honey bees makes that approach to studying sex ratio conflicts unproductive, it may be possible to approach the question through behavioral observations. In honey bees, males and queens are produced in specialized cells. There is feedback in comb construction (Free, 1967; Free and Williams, 1975), resulting in a fairly constant proportion of drone comb in unmanaged colonies (Seeley and Morse, 1976), but comb may be used for storage of honey and pollen, making it unavailable for egg laying. Observations and experiments on the treatment of empty and full drone and worker comb by workers and queens might reveal behaviors which follow the prediction that queens lay more readily in drone comb, but that workers limit the availability of suitable (empty and cleaned) drone cells. Also, workers sometimes remove queenlaid drone brood. An analysis of this behavior in light of the theory of of sex ratio conflict could prove revealing.

The potential conflicts between queens and workers in sex ratio also relate to the regulation of the number of queens reared and afterswarms produced. These have been analyzed theoretically by Visscher (1993), but not in relation to the production of males.

\section{ALLOCATION OF INVESTMENT AMONG QUEENS}

Only the queen honey bee is able to mate and lay fertilized eggs, so all female reproductives will be her progeny. However, because of polyandry, the relatedness of these new queens to particular workers can vary sharply. If a worker shares the same father as the new queen, she will be related by 0.75 , otherwise only by 0.25 . In this setting, the payoff to an individual worker is three times as great from a sister queen of the worker's subfamily as from a half sister. This difference might set the stage for selection to favor nepotism in queen rearing, i.e. recognition of relatedness differences and 
behavior which favors the rearing of more closely related individuals. This area has received considerable study, but awaits full resolution.

\subsection{Process and product}

Studies of nepotism can examine the processes involved, such as the visitation of larvae by nurse workers, or the products of these processes, the distribution of queens reared, or a combination of the two approaches. Studies with all of these approaches have been published (see below). With regard to studies of the end products of nepotism in queen rearing, even if strong nepotism occurred, it would not be detectably different from the effects of no nepotism unless the subfamily distributions among nurses and available larvae differed, but would still represent an evolutionarily stable strategy (Visscher, 1986a). Thus end-product studies of nepotism must either introduce distribution differences or rely on their being produced by other processes such as sperm utilization patterns, queen turnover, or genetic differences in labor patterns.

\subsection{Studying product: the number of queens reared}

Several scientists independently began studies on the question of nepotism in queen rearing. The first of these published was that of Page and Erickson (1984). In their study, young larvae laid in worker cells were transferred to queen cups (the primorida of queen cells), and colonies were presented with sister larvae from their own colony, and less-related larvae from a foreign colony. The colonies were headed by sister queens, each instrumentally inseminated with the semen of a single drone, so that the normal diversity of subfamilies was not present, own-hive larvae were related to the rearing workers by
0.75 , and foreign-hive larvae were related with a coefficient of $0.25-0.375$. The bees reared an average of $10 \%$ of the presented larvae, and there was a significant preference for the larvae from their own colony (figure $3 A$ ). There was greater preference for nestmate larvae in those replicates of the experiment in which the total proportion of transferred brood accepted was less.

Breed et al. (1984) reported negative results in three independent experiments conceptually similar to Page and Erickson's (1984) study. One experiment exchanged entire frames of brood between queenless colonies, and two transferred larvae into royal jelly in queen cups. The colonies in each case were naturally mated, with a full normal subfamily diversity among the larvae and rearing workers, and the pairs of colonies were completely unrelated to one another (and, in the third experiment, of different races, Apis mellifera carnica and A. m. mellifera). In the second and third experiments (figure $3 C, D$ ) the bees reared 45 and $62 \%$ of the transferred larvae, respectively (the figure $3 B$ experiment did not transfer the larvae; an average of 2.1 queen cells per frame of worker brood were reared). In all three experiments the numbers of nestmate and foreign larvae reared were very similar, and not significantly different.

Visscher (1986a) performed a series of studies testing for preferential rearing of more closely related brood, and the nature of the model and recognition system. His first experiment (figure $3 E$ ) was similar to those of Breed et al. (1984), transferring larvae into royal jelly in queen cups, and, as in experiments in $3 \mathrm{C}$ and $3 \mathrm{D}$, had relatively high acceptance $(57 \%)$, and no evidence of nepotism. In a second experiment (figure $3 F$ ), where eggs rather than larvae were transferred, the acceptance was much lower $(13 \%)$ and there was a significant preference for nestmate over 
foreign-hive eggs, similar to Page and Erickson's (1984) result in figure $3 A$.

None of the above experiments included controls for 'hive odor' effects, so that preferences for nestmate eggs could be based on environmentally derived cues rather than genetic ones. Visscher's (1986a) third experiment (figure 3G) addressed this issue by giving bees a choice between larvae from two foreign hives, one of which was related to the rearing colony and the other was not. The bees reared $5 \%$ of the presented brood, with a significant preference for related, foreignhive larvae over unrelated foreign-hive larvae, which supports the idea that genetically based cues underlie the selective rearing in these experiments. (This experiment included two variants; the first involved singly inseminated queens, whose colonies lacked normal subfamily diversity, were not as populous, reared $4 \%$ of transferred brood, of which $58 \%$ were related, while the second were naturally mated, presumably to many drones, and reared $7 \%$, of which $65 \%$ were related. Woyciechowski (1990) pointed out that the results from the first subset did not attain statistical significance, but this was because of smaller numbers of queens reared in these weak colonies - an effect he commented on - not to a lack of bias).

Although the experiment in figure $3 G$ showed that bees could use genetic cues, it could be that the bees simply discriminated against brood with odors dissimilar to the brood which they were accustomed to rear, a process which would not lead to discrimination among subfamilies in a normal colony. Visscher (1986a) unlinked familiarity and relatedness in an experiment (figure $3 \mathrm{H}$ ) in which brood was swapped between colonies. The bees continued to prefer related, unfamiliar brood to unrelated, familiar brood, suggesting that the most likely mechanism for nepotism in brood rearing is self-referent phenotype matching (Holmes and Sherman, 1983) That is, a bee learns her own phenotype (probably odor) and evaluates kinship of other bees by their degree of phenotypic similarity to this learned template (Visscher, 1986a).

Woyciechowski (1990) performed experiments similar to $3 \mathrm{E}$, but using instrumentally inseminated queens (with the semen of either one or several males). The bees reared $5 \%$ of the presented brood, but there was no preference for rearing related over unrelated brood (figure 3I).

In these experiments, reciprocal transfers of brood provide an important control, as pointed out by Page and Erickson (1984), because colonies might vary both in the attractiveness of their brood for queen rearing and in their tendency to rear queens. If these both occurred and were positively correlated (e.g. perhaps wellfed colonies had more attractive brood and

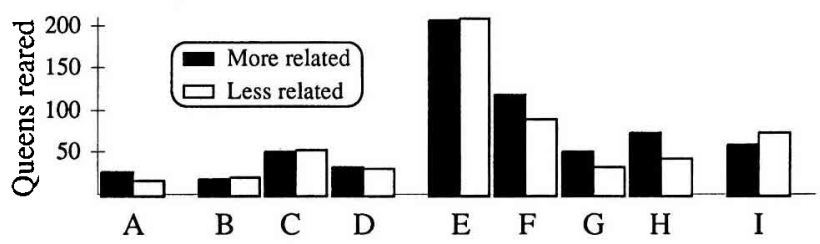

Figure 3. The number of queens reared from closely related (usually nestmate) and less related (usually foreign-hive) eggs or larvae in experiments transferring larvae between colonies. The studies shown are A) Page and Erickson (1984); B-D) Breed et al. (1994); E-H) Visscher (1986a); I) Woyciechowski (1990). 
were also more inclined to rear queens), it would result in artifacts supporting nepotism. If negatively correlated, it could mask nepotism that actually occurred. Page and Erickson (1984) and Visscher (1986a) explicitly checked their data and did not find such correlations. The second two studies of Breed et al. (1984) had a design and reporting of data which allow this to be checked, and such correlations are lacking. This cannot be evaluated for Breed et al.'s (1984) first study or Woyciechowski's (1990) because of experimental design and/or reporting. Another confounding effect is that the probability of transferred brood being reared is strongly affected by its position in the rearing colony (Visscher, 1986b). All of the experiments in which brood was transferred to queen cups controlled for this by alternating brood from different sources, but only the experiments in figure $3 E-H$ used statistical methods which preserved the spatial pairing information. However, in contexts of low acceptance the results of the different statistical approaches are likely to differ only slightly.

The differing results of these studies follow patterns, but these are not entirely consistent. All of the experiments involving transfer of larvae into royal jelly ( $f i g$ ure $3 B-D$ ) reported equal rearing, while 'dry' transfer of larvae (figure $3 A$ ) and most experiments transferring eggs (figure $3 F-H$ ) found kinship preferences, but Woyciechowski (figure 3I) did not. It seems likely that royal jelly masks odor differences, and it may shift the context from acceptance to continuation of feeding. Interestingly, as pointed out by Page and Erickson (1984), lack of discrimination against non-nestmate larvae is one of the foundations of commercial queen rearing, but there royal jelly is usually used.

The age of the brood transferred may have an effect on the results, and varied between these studies. The experiments $3 \mathrm{~A}$ used 'recently hatched' larvae, 3B pre- sumably had brood of all ages, and $3 \mathrm{C}-\mathrm{E}$ followed standard queen rearing practice, which uses egg up to 2 days after hatching. $3 \mathrm{~F}-\mathrm{H}$ used eggs from 0 to $24 \mathrm{~h}$ old, and $3 \mathrm{I}$ used eggs which had not hatched after being removed from the queen from 3 or 4 days, so that hatching would be expected no more than several hours after grafting (and so might have selectively used slowdeveloping larvae).

Page and Erickson (1984) pointed out that in their experiments there was stronger discrimination when the bees reared a smaller proportion of the presented larvae, and that the bias toward nestmate larvae increased with time (though not significantly so). The studies in figure $3 C-E$ had high acceptance of larvae, and showed no preferences. Woyciechowski (1990) presented exceptions to several of these patterns: he found no nestmate bias even with transfer of eggs when the bees accepted low percentages of transferred brood. He did not, however, take data on the number of sealed cells, but it seems unlikely that the relative numbers would have changed much from 4 days after hatching to sealing.

\subsection{Studying process: the behavior of attendants to queen cells}

Noonan (1986) took a very different approach from the above studies to the question of nepotism in queen rearing. She employed the cordovan marker; bees homozygous for the cordovan mutant allele have red-brown cuticle where wildtype bees are black. In her colonies a cordovan queen was instrumentally inseminated with semen from one cordovan and one wild-type drone, so that the subfamilies in the colony could be visually distinguished. She then recorded the subfamily identity of workers as they visited developing queen cells, and then later the subfamily of the queen reared from each 
cell. She found a significant bias in favor of queen larvae of the visiting worker's subfamily in both total number of visits, and in visits in which the worker was inferred to have fed the larvae in the cell (figure $4 A$ ). The cordovan workers were more frequently involved in visiting queen cells than wild-type workers (figure $4 \mathrm{C}$ ), either because they comprised more of the colony, or because the line from which they came had more of a predisposition toward queen rearing. Also cordovan queens received more visits than wild-type queens (figure $4 B$ ), indicating a further difference in the two lines. But when these differences are factored in, workers visited queens of their own subfamily about $10 \%$ more than would have been expected if the frequency of visitation to queens of the two subfamilies was independent of the subfamily of the worker visiting.

Noonan's approach has the considerable strength of observing the process of discrimination between subfamilies, whereas the above experiments all involved introduction of brood from foreign colonies, an unnatural context. The observation method has the disadvantages that it involves an unusually small, queenless colony with lower-than-normal subfamily diversity, and involves a mutation that apparently affected feeding interactions (cordovans received more feedings, and may have been more likely to be nurses), and which may make marked bees especially distinctive (see below).

Another study that focused on the processes involved in differential queen rearing (though more indirectly) was that of Page et al. (1989). In this experiment, queens were instrumentally inseminated with semen from three drones bearing different $\mathrm{MDH}$ alleles, so that the worker offspring of these drones could be identified by electrophoresis (except that six of ten colonies had queens heterozygous at $\mathrm{MDH}$, and so ambiguous offspring phenotypes were divided between alternative subfamilies based on the sperm use frequencies inferred from unambiguous phenotypes). Larvae from these colonies were then transferred from worker cells into queen cells, and the workers reared some of these larvae as queens. Three samples

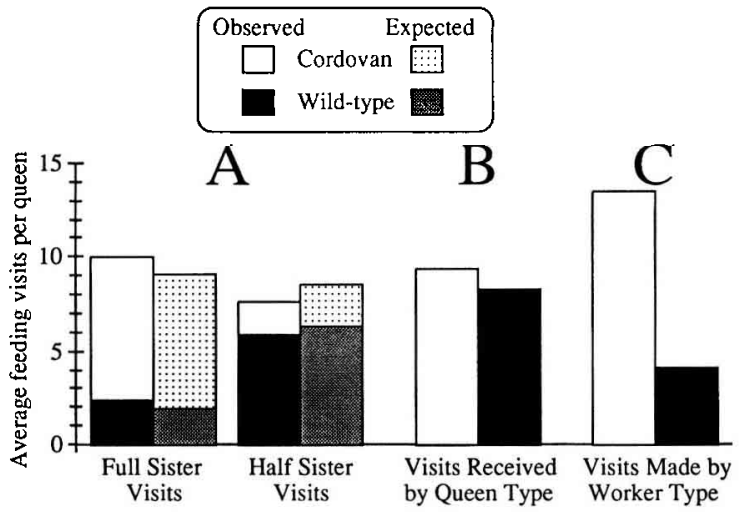

Figure 4. The average number of feeding visits observed by Noonan (1986) to queen larvae later identified as cordovan or wild-type phenotype (and thus subfamily). These visits are displayed by A) relationship of the visiting bee (and the expected number if bees visited randomly); B) the phenotype of the queen visited; and C) the phenotype of the visiting worker. 
were collected for each of three trials from each of ten colonies, consisting of all the larvae which were being reared as queens (Q), 40 immature workers from the same pool as the larvae transferred to the queen cells (L), and 40 adult workers collected from the surface of the developing queen cells, and so were presumptive nurses engaged in queen rearing $(\mathrm{N})$.

For each trial, Page et al. (1989) identified a focal subfamily as the one which was most strongly overrepresented in the nurse sample relative to the larval sample (i.e. that had the highest relative likelihood ratio $\mathrm{RL}_{\mathrm{i}}$ of nurse to larval proportions of subfamily $\mathrm{i}$ ). They reasoned that if nepotism were occurring, it would result in a positive 'deviation', i.e. a larger number of queens of this subfamily would be reared than expected $E\left(Q_{i}\right)$ on the basis of the frequency of subfamily $i$ in the larval pool and the number of queens reared. They calculated these quantities and found an overall excess of $Q_{i}$ over $E\left(Q_{i}\right)$. They used a Monte Carlo procedure to evaluate whether the observed deviation was larger than expected by chance.

Oldroyd et al. (1990) correctly pointed out that the analysis of Page et al. (1989) was flawed, and contained a systematic bias toward positive results. The problem was that assignment of the subfamily with highest $R L_{i}$ and generation of expected number of queens reared $E\left(Q_{i}\right)$ were not independent. Subfamilies for which sampling effects led to low representation in the larval sample would have both high $\mathrm{RL}_{\mathrm{i}}$ (proportional to $\mathrm{N}_{\mathrm{i}} / \mathrm{L}_{\mathrm{i}}$ ) and low $\mathrm{E}\left(\mathrm{Q}_{\mathrm{i}}\right.$ ) (proportional to $\mathrm{L}_{\mathrm{i}}$ ). Random sampling would not have its usual balancing effect because the analysis omitted data from low-RL subfamilies. Thus the focal-subfamily approach led to a systematic bias with more observed than expected numbers of queens in the (high-RL) subfamilies chosen for analysis. Oldroyd et al. (1990) demonstrated that randomly generated data resulted in a positive devia- tion due to this bias. The Monte Carlo simulation used to evaluate the significance of the deviation did not share the bias of the calculation of the deviation from the data, because it assigned focal subfamily extrinsic to the simulated sample (based on $\mathrm{RL}$ in the experimental data for the corresponding subfamily). As a result it described a null-hypothesis distribution centered on zero, and incorrectly assigned statistical significance to randomly generated data. Because of this, Oldroyd et al. (1990) concluded that Page et al. (1989) contained no evidence for nepotism in queen rearing. Visscher (1990) attempted to correct the Monte Carlo analysis, and found that Page et al.'s (1989) data did not fit the null hypothesis, but further examination showed even modified simulations were not statistically precise. Page and Robinson's (1990) reply to Oldroyd et al.'s (1990) criticism alluded to standard statistical tests on their data, but did not present them or their results, and concluded that "conclusive demonstration of nepotistic queen rearing remains elusive".

I have reanalyzed the data of Page et al. (1989), using more conventional statistical techniques, and including all data, and invoking the following logic. If bees rearing queens are practicing nepotism, they should influence the distribution of the subfamilies among the queens in the direction of their own subfamily distribution. This will be constrained to a greater or lesser degree by larvae available to rear. I found that the data of Page et al. (1989) satisfied three conditions: 1) there were differences in subfamily distribution between the bees participating in rearing queens, and the larvae from which the queens were reared (otherwise nepotism, even if occurring, would be undetectable); 2) a difference was created by the rearing behavior of the bees between the distributions of subfamilies among the queens and among the larvae from which they are reared (i.e. there was differential rearing); 
3) this differential rearing brought the subfamily distribution of the queens reared closer to that of the nurses than it was initially (i.e. the differential rearing was in a nepotistic direction).

To test the first of these conditions, I performed a $\chi^{2}$ test of heterogeneity between the counts of nurses and of worker larvae in each subfamily, for each trial. In this test, and those below, when expected values fell below two (rarely) I collapsed categories by pooling the lowest count cell with the lower of the other two cells. Pooled over the 30 trials, this yielded a total $\chi^{2}$ of 178.3 (d.f. $=58$ ), indicating that there was a highly significant $(P<0.0001)$ difference between the distribution of subfamilies among the nurses and the larvae. This difference could be a result of genetically based differences in the probability of participating in brood care, as suggested by Page et al. (1989). However, a simple genetic model would predict that between trials within colonies the same subfamily would be over-represented; in nine out ten colonies the highRL subfamily differed between replicates (e.g. figure 5). Different subfamily distributions could reflect a more complex genetic effect, changes in sperm utilization patterns by the colony's queen over time, differential survival of workers, or other effects.

To test the second condition, I performed a test of heterogeneity between the counts of queens and of larvae in each subfamily, for each trial. This again showed a significant difference (pooled $\chi_{52}^{2}=70.4, P<0.05$ ), indicating that the subfamily distribution did change from the larval pool to the queen sample. The analysis that Oldroyd et al. (1990) performed on the same data did not show such an effect because they pooled all trials from each colony, which is inappropriate since there is clearly heterogeneity between trials, which they pointed out.

To test the third condition, I compared the goodness of fit in terms of subfamily proportions of the larval distribution to the nurse distribution, and of the queen distribution to the nurse distribution. I calculated a goodness of fit (GOF) statistic (as in a chi-squared GOF test) for each trial, and pooled the statistic across trials. I found that the fit of queens to the nurse distribution $\left(\mathrm{GOF}_{51}=264.4\right)$ was closer than that of the larvae to the nurses $\left(\mathrm{GOF}_{56}=397.9\right)$, an example of this can seen in figure 5 .

This reanalysis finds that the data of Page et al. (1989) does support the hypothesis that worker bees behave nepotistically

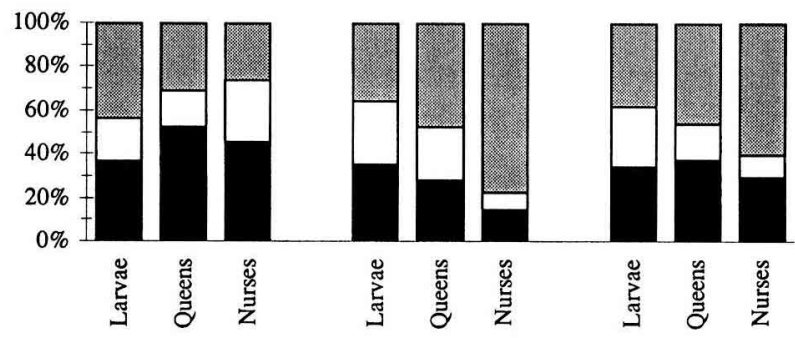

Figure 5. Frequencies of the three subfamilies (different shades, always totaling $100 \%$ ) in three replicates on one colony (number 4 456) from the data of Page et al. (1989). Different subfamilies were overrepresented among the nurses relative to the larvae in different replicates (this was true for nine of ten colonies). The expectation of nepotism is that subfamily distribution among queens would be closer to that of nurses than the distribution among the larvae is to the nurses. This condition was met here, and in the experiment as a whole. 
during queen rearing, preferentially rearing larvae more closely related to themselves. There are, however, some objections which might still be raised. The first is the question of independence between multiple tests on the same colonies. The individuals involved are clearly different, and the subfamily distributions are different, suggesting that the data should not be lumped across trials, but they may lack complete independence. Second is the effect of assigning subfamilies in colonies with heterozygous queens. The method followed by Page et al. is a maximumlikelihood estimate, but it is subject to sampling error, as pointed out by Oldroyd et al. (1990). Such errors are not likely to affect the test statistics I calculated, but may affect the null hypothesis distribution, though simulations I did to examine this suggested little effect.

The experimental design used by Page et al. (1989) is a powerful one, and preserved the most natural conditions among experiments on queen-rearing nepotism. Their study did impose an artificially small number of subfamilies in the colonies used, and while the genetic lines used to make subfamilies identifiable had all recently been isolated from the same population, some possibility exists of linespecific differences which would aid discrimination as suggested by Carlin and Frumhoff (1990). However, this random differentiation between the genes of different drones is presumably the source of variation on which intracolony discrimination in wholly natural conditions acts, as well. The experiment should be repeated more rigorously, without the heterozygous queens or pseudoreplication uncertainties.

\subsection{Effects of subfamily diversity and genetic markers}

Breed et al. (1994), reviewing studies of nepotism in queen rearing, stated that
"Page's and Visscher's experiments had been criticized" (unreferenced) for restriction of the number of subfamilies and possible effects of marker genes or genetic lines, and that no controls for these effects were included in the experiments. However, neither Page and Erickson (1984) nor Visscher (1986a) used genetic markers or selected lines, and nearly all of Visscher's (1996a) experiments were carried out with open-mated colonies which would have the full complement of subfamilies.

Hoogendoorn and Velthuis (1988) reported that recognition of adult nestmates showed a subfamily bias in contexts with few subfamilies but not when in colonies with many subfamilies. However, Page et al. (1990) pointed out that this effect was due not to discrimination differences but to loss of statistical power with the smaller sample sizes that result from greater subfamily diversity. Moritz and Heisler (1992) reported loss of kinship-correlated asymmetries in a workerworker feeding assay with increasing subfamily diversity. Although they argued that decreasing variance with more subfamily diversity supported their interpretation, this effect on variance might be expected if the number of trophallactic exchanges were Poisson distributed, so that the lower variance at lower means would be expected under either model. Simulations of the effect of decreasing numbers of closely related bees in groups of constant size show that the expectation in this experiment is quite variable with different relative preferences between subfamilies (figure 6). While the simulation results do not mirror those of the experiment (the upper line shows a trend opposite the real data), and the model may or may not describe the behavior well, these results do suggest that the null hypothesis expectation of unchanging preference results with constant degrees of kin preference are probably violated due to 

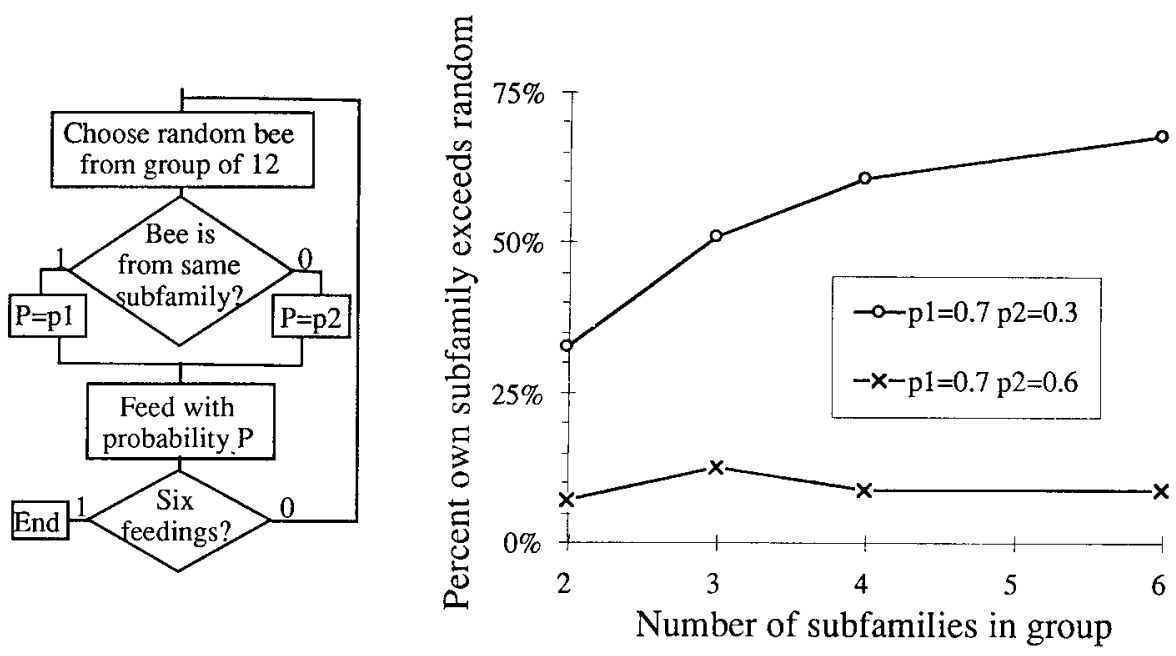

Figure 6. A stochastic simulation to evaluate effects of different kin-preference parameters on an experiment like that of Moritz and Heisler (1992). A program diagrammed on the left was run for 1000 replicates. The graph on the right depicts the percent difference between the average deviations in the number of feedings received by bees of the same subfamily as the donor bee and the expectation of uniform distribution of feedings within the group. The results for two different pairs of parameter $\mathrm{p} 1$ and $\mathrm{p} 2$ are shown.

stochastic effects of group composition, and the distribution of such data may not meet the assumptions of the statistical tests used in Moritz and Heisler's (1992) study.

The cordovan marker is a single locus mutation, apparently preventing synthesis of normal melanin (Tucker, 1986). Visscher and Seeley (see Visscher, 1990) observed interactions of marked workers with an assay like that of Breed (1983) but with the marker coming from an heterozygous $(\mathrm{cd} /+)$ mother mated with a single cd drone so that all bees were equally related, but some were phenotypically cordovan and others wild-type. The bees bearing the cordovan marker were treated differently than the wild-type bees. Frumhoff (1991) reported similar results for a feeding assay in observation hives. These effects may result from odor differences arising in melanin formation or lack of it in cordovan bees (with possible buildup of intermediary products in the absence of end-product inhibition). Alternatively they may result from the effects of genes linked to the cordovan locus. In the former case it is unlikely that larvae, which do not synthesize melanin, would have phenotypic differences due to the cordovan allele. As indicated above, in Noonan's (1986) study, the cordovan bees may have behaved differently as adults (more cordovans fed queens, but their numbers among workers of queen rearing age were not reported) and were treated differently as larvae (cordovans were fed more often). These differences could be due to the cordovan allele, but are more likely due to linkage, particularly since half of the genome of the bees of each subfamily were linked via their common cordovan or wild-type father.

Breed et al. (1994) conclude that "use of the cordovan marker and two-subfam- 
ily colonies must be regarded as fatal experimental deficits" because these might result in discrimination where none would occur in unmarked or more diverse colonies. This conclusion is probably not justified by the present evidence, particularly with respect to subfamily diversity. As pointed out above, very similar results on nepotism in queen rearing were obtained in both two-subfamily and multisubfamily experiments (and with and without biochemical or body-color markers). Nonetheless it seems possible that subfamily diversity could affect bees' capability to make accurate discrimination (particulary if the weakness of these effects is due to cue ambiguity, see below). Recently developed molecular tools, particularly DNA microsatellites, provide promising tools for overcoming these uncertainties, but they do so at the price of more complex methods and loss of statistical power, which will have to be corrected with larger experiments.

\subsection{Conclusions}

Studies of nepotism in queen rearing have reported a mix of positive and negative results. Most, but not all of the negative findings are explained by the context of high acceptance and effects of royal jelly. Woyciechowski's (1990) experiments had a design and sample sizes that would have been expected to detect effects of the magnitude reported in other studies. One possible (though unsatisfying) explanation of such variation in results is variation among different colonies or populations of bees in either the cue diversity or tendency toward nepotism. Consistent with this possibility, Visscher (1986a) reported greater degrees of nepotism in some colonies than others.

The positive results have come from a variety of experimental techniques, each of which can be criticized as introducing unnatural elements which might influence results (as the authors generally acknowledge). Visscher's (1986a) brood transfer experiments eliminated many potential confounding factors, but still could be explained by the effects of genetically determined queen-derived odors which were similar between related queens. Noonan's (1986) results could have been affected by differences in the behavior of bees bearing the cordovan genetic marker or odors distinguishing cordovan and wildtype larvae. Page et al. (1989), in addition to a flawed Monte Carlo analysis, made assumptions of independence of replicates on the same colonies, and the distribution of subfamilies where markers were ambiguous, that might undermine the statistical significance of their results. However, these various studies do not share the same weaknesses, and yet arrive at similar conclusions. In summary, the preponderance of the evidence favors that weak nepotism in queen rearing does occur in honey bees. However, the evidence is equivocal, and the question merits further research.

It is also clear from the studies that have been carried out that nepotism in queen rearing is at best a fairly weak effect. In the brood-transfer studies, the expectation would be that more related larvae would be universally preferred, and exclusively reared. Instead, even in experiments where nepotism occurred, about $40 \%$ of the brood reared as queens was unrelated to the rearing workers, so about $20 \%$ more related queens were reared than expected with no nepotism. In Noonan's (1986) study, only about $10 \%$ more within-subfamily feeding visits were made than expected if there was no kin discrimination. In Page et al.'s (1989) study, the distribution of subfamilies in the larval pool from which queens were reared constrains the possible distribution of the queens reared, but it was not so different from the nurse distribution (although highly sig- 
nificantly so) that a strong nepotism effect could not have made a queen sample which matched the nurse sample distribution nearly perfectly.

As pointed out by Keller and Reeve (1994), experiments on reproductive skew in general, including those of kin recognition in honey bees, have focused on the mean effect. Equally interesting is the variance: are there different degrees of nepotistic behavior both within and between colonies, as theoretical results (Ratnieks and Reeve, 1992) suggest might evolve under the mating system of honey bees? Visscher (1986a) reported differences in the strength of nepotistic effects among colonies. Some of the variable results found in studies of nepotism could be a result of sampling in populations which vary for this trait.

The true degree of kin bias and the reason that it remains weak deserve further experimental examination. It may be that the low efficiency of nepotism reflects limitations on the discrimination ability of bees due to a paucity of cues or ambiguity of cues present in larvae which are used to glean kinship information (Visscher, 1986; Ratnieks, 1991). Indeed, it seems remarkable that there is any information at all that bees could use to make kinship judgments of newly hatched larvae, especially since the most likely mechanism they use is a learned reference of their own odors as adults (Visscher, 1986a), and queen rearing nepotism itself would be expected to reduce the allelic diversity used to determine paternity (Ratnieks, 1991).

It also may be that nepotism is constrained by the costs it places on the colony level component of an individual's fitness. In the extreme, this is clearly sufficient: behavior that involved bees of each subfamily killing all developing queens of other subfamilies would prevent any queen rearing. Ratnieks and Reeve (1992) showed that in singly mated species, queen-rearing nepotism is unlikely to be selected, but is likely under polyandry, unless it sufficiently reduces the efficiency of workers as workers. This 'sufficient' reduction in efficiency is easier to satisfy at high mating frequencies such as are found in honey bees than at lower frequencies, so that queen-rearing nepotism is less likely to be selected both in monandrous and highly polyandrous species than in polyandrous species with lower mating frequency.

Another possibility that has not been investigated is that nepotism is constrained by some kind of policing mechanism similar in principal to what has been found regarding worker laying (see below). An individual bee's biasing of the colony's queen production in favor of her subfamily has a direct cost to bees of other subfamilies, and in a honey bee colony the bees of other subfamilies always constitute a great majority. If workers could detect nepotistic behavior and impose reproductive costs on nepotists, the expected effect would be a reduction in biases in queen rearing that might explain the weakness of this effect found in empirical studies.

\section{MATERNITY OF MALE REPRODUCTIVES}

\subsection{Worker production of adult males}

In honey bees, workers have ovaries, but cannot mate. Thus, they are capable only of laying unfertilized eggs which develop into males. As reviewed by Bourke (1988), it is well known for honey bees and many other social insects that if a colony loses its queen, workers will begin to lay large numbers of eggs. Until recently, however, there was not a clear answer about how much worker reproduction took place in queenright colonies. Mackensen and Roberts (1948) reported 
the existence of genetically marked workers that must have developed from workerlaid eggs, as did Page and Erickson (1988), who observed that the occurrence of these in drone cells suggested a special adaptation of workers different from unmated queens. Several studies [reviewed in Bourke (1988), Visscher (1989)] found varying small amounts of ovary development among workers in queenright colonies, but nonetheless the prevailing picture of bee colonies was that workers were sterile when the queen was present (e.g. Winston, 1987).

Quantitative data on the production of mature drones from worker eggs was provided by a 2 -year study of 12 colonies by Visscher (1989). In this study, the occurrence of about 1.2 per 1000 of the colonies' drones coming from workers raised questions about whether such a small number might be artifacts. This was tested by use of a control colony in which artifacts from imperfect markers or back-mutation at the cordovan locus would have produced wildtype drones in the control colony; none were observed. Nor did these drones develop from fertilized eggs, since the worker-produced drones were of a size indicating that they developed in drone cells, not worker cells, where the queen would be expected to lay fertilized eggs. This test was overlooked by Van der Blom (1991) in his claim that Visscher's (1989) results might be explained as paternate drones.

\subsection{Selection against worker reproduction}

The existence, but rarity, of worker reproduction in queenright colonies posed the question of why it was so rare, since the coefficient of relatedness of workers is twice as great to their own sons as to their mother's sons. Selection might have produced mechanisms limiting worker reproduction through the interests and actions of the colony's queen, the individual workers themselves, or the other workers in the colony.

Queen control through pheromones inhibiting ovary development has long been suggested as the mechanism limiting worker reproduction [reviewed in Bourke (1988)]. However, a detailed examination of the timing of queen removal and worker ovary development, and the behavior of 'messenger' workers distributing queen pheromones (Seeley, 1979) generally support the view that the queen pheromones function as a signal of queen presence, with worker ovary suppression as an indirect effect, rather than a sterilizing drug (Seeley, 1985; Visscher, 1989; Keller and Nonacs, 1993; Seeley, 1995).

A reduction in colony efficiency resulting from a worker laying eggs rather than specializing completely on indirect reproduction (through rearing her mothers offspring) could conceivably be great enough to favor worker sterility. However, calculations that have been done do not support this idea [reviewed in Visscher (1989)]. This situation leaves the most plausible explanation for the rarity of worker sterility as the mutual policing of reproduction by the workers, first proposed by Starr (1984), and developed theoretically by Woyciechowski and Lomnicki (1987) and Ratnieks (1988). Although each worker is most closely related to drones she herself might produce, in a polyandrous honey bee colony most of the workers will be half sisters to any given worker, and these will be less closely related to her sons than they would be to the queen's sons (figure 2), so that the only stable colony-wide compromise would be to allow production of male (and female) reproductives only by the queen.

\subsection{Mechanisms of worker policing}

This 'worker policing' could occur at any stage, before or after laying of eggs. 
Visscher and Dukas (1995) induced workers to develop their ovaries (by separation from queen pheromones) and then reunited the colonies, and found that apparently aggressive mandibulation received from nestmates was correlated with the degree of ovary development of the recipient workers. This shows that the bees can detect cues associated with ovary development, and suggests that aggressive behavior may be a mechanism suppressing the ovaries of honey bee workers in queenright colonies. Similar behavior occurs in queenless colonies (Sakagami, 1954) though it does not completely suppress ovary development. The mandibulation behavior looks very much like that described among Polistes wasp foundresses that are correlated with ovary regression in that species.

Ratnieks and Visscher (1989) showed that honey bees also have a strong mechanism of worker policing after eggs are laid. In this experiment, eggs from laying workers separated from the queen as above were substituted for eggs laid by the queen in drone cells, and these eggs' treatment was compared to queen-laid eggs which were similarly manipulated. After $24 \mathrm{~h}$, only about $1 \%$ of the worker-laid eggs were still in the comb, while most of the queen-laid eggs remained.

A possible mechanism for this policing would be kin recognition, since workers would be related by 0.25 to the queen's eggs and by 0.125 and to most other workers' eggs (figure 2). However, since Ratnieks and Visscher's (1989) results were nearly identical when the transfers took place between colonies, where the relatedness was 0 to both groups of eggs, this did not appear to be the mechanism. Ratnieks (1995) showed that instead queen versus worker egg recognition probably is mediated by a pheromone produced in queens' Dufour's gland and deposited on queen-laid eggs. Although these facts make it less likely, we cannot exclude kin recognition as a mechanism for selective cannibalism among the worker eggs. Robinson et al. (1990) reported that in queenright colonies particular subfamilies were especially frequently observed laying eggs, but this often did not correspond to the distribution of subfamilies among the adult drones reared. As they pointed out, one process which could produce such a pattern is selective removal of eggs or larvae, possibly based on kin recognition.

\subsection{Worker laying in queenright colonies}

The presence of strong worker policing mechanisms apparently accounts for the rarity of adult drones derived from worker eggs, but the effect could be either indirect (the low probability of success results in workers not attempting to lay) or direct (many eggs are laid but then removed by worker policing). Three recent studies bear on this question.

Ratnieks (1993) showed that in a colony separated by a queen excluder, eggs were often found above the excluder. Ratnieks argues persuasively that eggs he saw must have been worker eggs, rather than moved queen eggs. However, it is known that bees will rear queens readily from transferred larvae placed above an excluder in circumstances where they will not rear them below the excluder, suggesting that bees above the excluder do not perceive themselves to be in a normal queenright colony. This raises the possibility that the eggs in Ratnieks' (1993) experiment were laid by partially queenless workers (though as Ratnieks pointed out, no emergency queen cells were reared from worker brood above the excluder, as would be expected in a fully queenless colony). Ratnieks (1993) and Visscher (1996) dissected, respectively, more than 10000 and 3000 workers and examined their ovaries; they found only ten and no workers, respectively, that 
had ovaries sufficiently developed to suggest that they were involved in oviposition, and only one of these had a full-sized egg in her ovaries.

Oldroyd et al. (1994) reported on an unusual colony discovered in a wide search of many colonies, in which more than 100 drone-sized cells above the excluder contained developing brood. Microsatellite markers established that these were laid by workers, and mostly by at least three workers of one subfamily. They concluded that these workers marked their eggs with queen-like pheromones, so that they escaped worker policing mechanisms. An alternative explanation would be that at least above the excluder, this colony behaved like a queenless colony toward worker-laid eggs, since these are accepted in queenless colonies. Thus this could be a result of a situation in which an even-lessthan-usual transfer of queen pheromone occurred across the excluder. The concentration of worker-laid eggs from one subfamily is consistent with the data of Robinson et al. (1990) from queenless colonies.

Visscher (1996) used electrophoretic markers to quantitatively examine the extent of worker laying in queenright colonies. The colonies in this study were naturally mated (to preserve a natural genetic structure) and had queens homozygous for one of the two less-frequent alleles of MDH. Frames of drone comb were introduced to the colonies and checked for the presence of eggs at 2 or $16 \mathrm{~h}$ intervals (usually there were no eggs). Since eggs retain the maternal MDH phenotype for at least 2 days after they are laid (Page and Robinson, 1994), electrophoresis of these eggs was used to assign them to the queen or her (mostly heterozygous) workers. Since some of the workers shared the queen's MDH phenotype, the estimate of worker-laid eggs was increased proportionally to the observed likelihood of homozygotes among each colony's workers.

Visscher found about $2 \%$ of the drone eggs in $2 \mathrm{~h}$ collections could not have been laid by the colony's queen, and most likely $2.75 \%$ came from workers. Since workerlaid eggs are rapidly removed, even the proportion found at $2 \mathrm{~h}$ intervals is a serious underestimate of worker laying. As shown in figure 7 , the probability that an egg laid at some time during the inspection

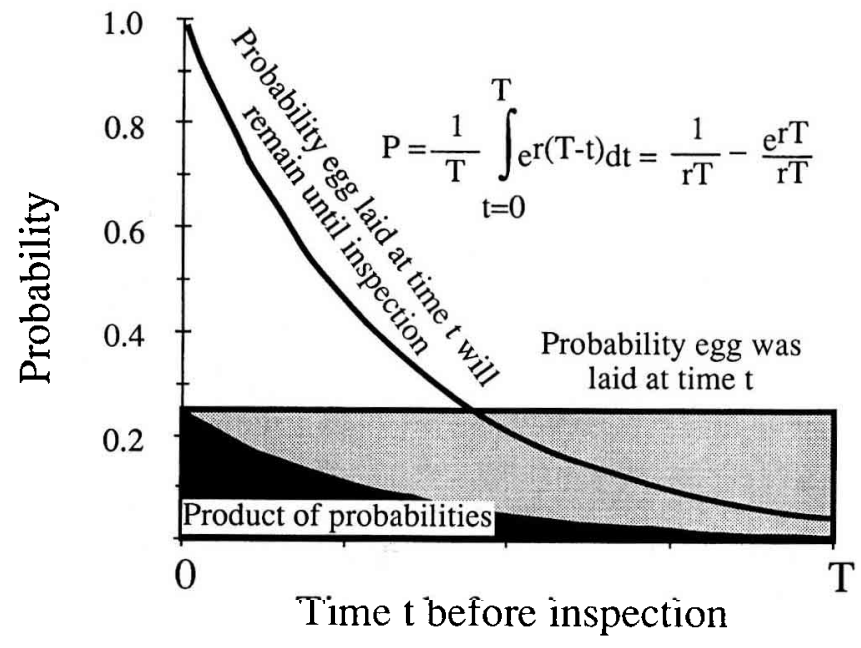

Figure 7. The mathematical model for extrapolating proportion of eggs found after an inspection interval $\mathrm{T}$ to the proportion laid before some were removed by policing. 
interval will remain to the end of the interval can be estimated by assuming they were laid with equal probability throughout the collection interval (the horizontal rectangle, with a height such that its area - the summed probability - is 1), and that after laying they were removed with a constant probability per unit time (shown by the exponential decay curve). The actual proportion of worker-laid eggs among justlaid eggs is then the proportion remaining (the observed datum) divided by the integral of the product of the two probability curves (the area shown in black). Using this method, empirical data on removal rates, and a simulation to correct for small-sample biases in chi-squared tests, Visscher (1996) showed that his data were consistent with workers in all his colonies laying between 4 and $14 \%$ of the male eggs collected, with a best estimate of $7.4 \%$.

\subsection{Conclusions}

Ratnieks (1993) and Visscher's (1996) results demonstrate dramatically more worker laying than has previously been appreciated. The order of magnitude change in proportion of worker-laid eggs after $2 \mathrm{~h}(2.75 \%)$ and after $16 \mathrm{~h}(0.29 \%)$ in Visscher's (1996) colonies provides an especially clear picture of the process of worker policing taking place among the eggs naturally laid in colonies.

The egg laying studies provide a snapshot of relatively few colonies and do not provide much information on seasonal pattern. Also, they introduced a perhaps unusual amount of empty drone comb in the experimental colonies, which could influence the level of laying of male eggs. However, this probably did not inflate the estimates of worker laying. Extra comb might equally well increase queen drone laying (see sex ratio, above). Furthermore, these levels of worker laying are in good agreement with the level of worker laying which, even after passing through a $99 \%$ efficient behavioral 'sieve' of policing mechanisms (Ratnieks and Visscher, 1989), would leave a small proportion (about 0.001 ) of worker-laid adult drones (Mackensen and Roberts, 1948; Page and Erickson, 1988; Visscher, 1989). It is likely that further studies will refine our understanding of worker laying, but probably what we know now is a good preview of the full picture.

Studies on the issue of the maternity of male reproductives in bee colonies have provided a powerful example of the application of evolutionary theory to predict non-obvious behavior, followed by empirical studies which document the kind of behavior predicted. This is particularly true for the issue of worker policing, where very strong behavioral mechanisms exist in honey bees that were unknown before their existence was predicted from first principles.

\section{THE BALANCE OF CONFLICT AND COOPERATION IN HONEY BEE COLONIES}

Are honey bee colonies superorganisms, which can be viewed as a single integrated and complex phenotype, or are they battlegrounds of individuals striving to maximize their own fitness by any means possible, constantly attempting to subvert shared reproductive pathways or working to prevent others from doing so? The studies cited here suggest that both occur.

Worker laying is far more common than previously thought, but it is nonetheless relatively uncommon. The vast majority of workers apparently are completely sterile, and the small number of workers per colony which do lay eggs together lay an order of magnitude less than the colony's queen. Studies on queen rearing nepotism have found it to be very weak, if 
they detected it at all. Furthermore, even with nepotism, if all bees practice nepotism to the same degree, it will result in a distribution of paternity among the queens produced identical to the absence of nepotism.

The result is, as Seeley (1995) pointed out, that the reproductives produced by a bee colony come nearly exclusively through a shared pathway (the queen), and, so far as we know, distributed nearly fairly in proportion to genetic distribution of the workers. These are the criteria for natural selection to favor the construction of elaborate integration without regard to its effects on individual reproduction, and in the social insects, and particularly the honey bee, we see the effects of this selection.

However, we again encounter a contrast between product and process. The reproductive product is nearly unbiased, paving the way for cooperation, but nonetheless the process which underlies this product displays considerable evidence of conflict. It is a situation analogous to a cold war, with equal attrition on both sides, and deterrence preventing escalation of the conflict. Recent theoretical work has enriched our understanding of the balance between conflict and cooperation. Ratnieks and Reeve (1992) showed that polymorphism might be expected in the balance of selfishness and cooperation. Reeve and Keller (1997) demonstrated that policing behavior is made more likely by many of the features which characterize honey bee colonies, including low cost of policing to group reproduction, high gain in reproduction for cheating individuals, and relatively low relatedness. Furthermore they demonstrated the interesting result that resolution of conflict through policing behavior in one area would be expected to increase selection for selfish behavior in other areas (because, as the total reproduction increases, slight biases in an individual's share become more valuable). This result suggests that the evidences of conflict we find in bee societies are not mere remnants of a strife-filled evolutionary past, but continuing gambits and counter-gambits in a dynamic interplay of cooperation and conflict. Societies of genetically distinct organisms are not expected to be either superorganisms or battlefields, but both. The honey bee society, as long appreciated by human observers, is a strong example of cooperative synergy. But even here, beneath the surface there is a fascinating story of attempts at selfish reproduction and mechanisms that keep these attempts uncommon and unsuccessful.

\section{ACKNOWLEDGEMENTS}

Rob Page generously shared his data for the reanalysis, and provided helpful useful critiques of this manuscript and other studies. One anonymous reviewer inspired some new analysis, as well as improving the presentation of the paper. My work in this area over the last decade has been supported by funds from NSF. Tom Seeley, Roger Morse and Paul Sherman provided formative input in this research program.

Résumé - Intégration de la colonie et conflit reproductif chez l'abeille mellifère (Apis mellifera L.). Les colonies d'abeilles, bien que fortement coopératives, sont composées d'individus génétiquement différents. La figure 2 représente la structure de la parenté au sein de la colonie. Ces individus distincts ont des avantages génétiques différents selon la façon dont les ressources de la colonie sont réparties parmi les individus potentiellement reproducteurs. La figure 1 montre les axes de ces affectations. A cause de cette disposition on peut s'attendre à des conflits entre les membres de la colonie. Cet article analyse les données empiriques qui prouvent l'existence de ces conflits dans la proportion des sexes, 
le népotisme lors de l'élevage des reines et la production de mâles par les ouvrières.

Le conflit relatif à la proportion des sexes est minime et difficile à mesurer chez les abeilles, mais des études comportementales pourraient fournir des indications.

Le népotisme lors de l'élevage des reines a été étudié à diverses reprises. Dans plusieurs expériences on a procédé à des transferts de larves entre colonies ( $f i g u$ re 3) avec des résultats variables; ces variations s'expliquent en grande partie par les différences dans les méthodes d'étude. Deux autres études du népotisme ont considéré le processus plutôt que le résultat, en regardant le comportement de soin aux larves au cours de l'élevage des reines (figures 4 et 5 ). Cet article réanalyse les données de l'une des études controversées (Page et al., 1989) et compare les méthodes et les résultats des autres. Les preuves existantes suggère qu'il existe bien un népotisme léger lors de l'élevage des reines, mais qu'il est probablement limité soit par les coûts de fitness au niveau de la colonie, soit par l'ambiguïté des signaux utilisés. Le mélange de résultats en partie positifs et en partie négatifs peut être dû à certaines différences dans les méthodologies ou au polymorphisme lié à ce caractère.

La ponte par les ouvrières est un phénomène beaucoup plus répandu qu'on ne l'a longtemps cru. Dans l'une des études, environ $7 \%$ des mâles pondus dans les colonies provenaient d'ouvrières. Néanmoins presque tous les mâles adultes sont issus de la reine car le « maintien de l'ordre » exercé par les ouvrières élimine presque tous les œufs qu'elles ont pondus ; s'appliquant aussi bien aux æufs pondus qu'au développement ovarien des ouvrières il peut être le responsable de la stérilité complète de la plupart des ouvrières.

Ainsi chez les abeilles, un conflit actif d'un faible niveau est sous-jacent à la coopération dans la reproduction. Des travaux théoriques récents suggèrent que le polymorphisme est présent dans l'équilibre entre caractères égoïstes et caractères coopératifs. Le conflit que nous voyons dans la société d'abeilles est le résultat d'une interaction dynamique entre la coopération et le conflit, semblable à une " guerre froide », où il y a usure des deux côtés et où la dissuasion empêche l'escalade du conflit. (C) Inra/DIB/AGIB/ Elsevier, Paris

\section{Apis mellifera / comportement social / népotisme / reconnaissance parenté / ponte des ouvrières}

\section{Zusammenfassung - Integration der Völker und reproduktiver Konflikt bei} Honigbienen. Honigbienenvölker stellen hochkooperative Einheiten dar, obwohl sie aus genetisch unterschiedlichen Individuen zusammengesetzt sind. Die Verwandschaftsstruktur innerhalb der Völker ist in $A b b .2$ dargestellt. Für die verschiedenen Einzeltiere erwachsen hierbei unterschiedliche Vorteile, je nachdem wie die Volksressourcen auf die zur Reproduktion befähigten Tiere verteilt werden. Abb. 1 stellt die Achsenrichtungen dieser Zuweisungen dar, durch deren Struktur sind Konflikte zwischen den Koloniemitgliedern zu erwarten. In dem vorliegenden Beitrag werden empirische Befunde zum Nachweis solcher Konflikte in Bezug auf das Geschlechterverhältnis, die Verwandschaftsbegünstigung bei der Königinnenaufzucht, und die Erzeugung von Männchen durch die Arbeiterinnen analysiert.

Der Konflikt über das Verhältnis der Produktion von Männchen und Weibchen ist bei Honigbienen gering und schwer zu messen. Verhaltensstudien können allerdings Hinweise erbringen.

Die Begünstigung von Verwandtschaft wurde in mehreren Studien untersucht. In 
einigen Experimenten wurden Larven zwischen Bienenvölkern ausgetauscht (Fig. 3), mit widerspruichlichen Ergebnissen. Diese Widersprüche können allerdings zum größten Teil durch Unterschiede der Untersuchungsmethodik erklärt werden. In zwei weiteren Studien wurde stattdessen das Pflegeverhalten während der Königinnenaufzucht betrachtet (Fig. 4 und 5). In diesem Beitrag werden Daten einer umstrittenen Studie (Page et al., 1989) nochmals analysiert, sowie die Methoden und Ergebnisse einiger anderer Studien verglichen. Die Last des bestehenden Beweismaterials unterstützt, daß bei der Königinnenaufzucht eine schwach ausgeprägte Verwandtenbegünstigung durchaus besteht, daß diese aber entweder durch Fitnesseinbußen auf der Ebene der Völker, oder durch Unklarheiten der verwendeten Signale eingeschränkt wird. Die Mischung teils positiver, teils negativer Befunde ist möglicherweise auf bestimmte methodische Unterschiede oder auf die Vielgestaltigkeit dieser Verhaltensanlage zurückzuführen.

Eilage durch die Arbeiterinnen ist wesentlich verbreiteter als bislang angenommen wurde. Während einer der Studien stammten $7 \%$ der männlichen Eier in den Völken von Arbeiterinnen. Nichtsdestoweniger stammen dann fast alle ausgewachsenen Drohnen von der Königin ab, da die von den Arbeiterinnen gelegten Eier fast vollständig durch die Arbeiterinnen wieder entfernt werden ('worker policing'). Dieses 'policing' könnte sowohl in Bezug auf gelegte Eier, als auch auf die Ovarienentwicklung für die vollständige Sterilität der meisten Arbeiterinnen verantwortlich sein.

Unterhalb der reproduktiven Kooperation bei Honigbienen besteht daher gleichzeitig ein aktive Konflikt auf einem niedrigen Level. Neue theoretische Arbeiten legen hierbei Vielgestaltigkeiten innerhalb des Gleichgewichts eigennütziger und kooperativer Verhal- tensweisen nahe. Der Konflikt, den wir in Bienensozietäten sehen, ist daher das Ergebnis eines dynamischen Zusammenspiels zwischen Kooperation und Konflikt, vergleichbar mit einem «kalten Krieg» mit gleichgewichtiger Zermürbungstaktik auf allen Seiten, und der Vermeidung von Konflikteskalation durch Abschreckung. (C) Inra/DIB/AGIB/Elsevier, Paris

\section{Verwandtschaftserkennung / Nepo- tismus / eierlegende Arbeiterinnen / Sozialverhalten / Apis mellifera}

\section{REFERENCES}

Adams J, Rothman ED, Kerr WE, Paulino ZL (1977) Estimation of the number of sex alleles and queen matings from diploid male frequencies in a population of Apis mellifera, Genetics 86, 583-596

Bourke AFG (1988) Worker reproduction in the higher eusocial Hymenoptera. $Q$ Rev Biol 63, 291-311

Breed MD (1983) Nestmate recognition in honey bees. Anim Behav 31, 86-91

Breed MD, Velthuis HHW, Robinson GE ( 1984) Do worker honey bees discriminate among unrelated and related larval phenotypes? Ann Entomol Soc Am 77, 737-739

Breed MD, Welch CK, Cruz R (1994) Kin discrimination within honey bee (Apis mellifera) colonies: an analysis of the evidence. Behav Processes $33,25-40$

Butler C (1609) The Feminine Monarchie. Joseph Barnes, London

Carlin NF, Frumhoff PC (1990) Nepotism in the honey bee. Nature 346, 706-707

Darwin C (1859) The Origin of Species. John Murray, London

Fisher RA (1958) The Genetical Theory of Natural Selection, 2nd ed. Dover, New York

Fraser HM (1951) Beekeeping in Antiquity. Univ of London Press, London

Free JB (1967) The production of drone comb in honey bee colonies. J Apic Res 54, 945-954

Free JB, Williams IH (1975) Factors determining the rearing and rejection of drones by the honeybee colony. Anim Behav 23, 650-675

Frisch K von (1967) The Dance Language and Orientation of Bees. Harvard University Press, Cambridge, MA, 
Frumhoff PC (1991) The effects of the cordovan marker on apparent kin discrimination among nestmate honey bees. Anim Behav 42, 854-856

Holmes WG, Sherman PW (1983) Kin recognition in animals. Am Sci 71, 46-55

Hoogendoorn K, Velthuis HHW (1988) Influence of multiple mating on kin recognition by worker honeybees. Naturwissenschaften 75, 412-413

Keller L, Nonacs P (1993) The role of queen pheromones in social insects - queen control or queen signal? Anim Behav 45, 787-794

Keller L, Reeve HK (1994) Partitioning of reproduction in animal societies. Trends Ecol Evol 9 , 98-102

Mackensen O, Roberts WC (1948) A Manual for the Artificial Insemination of Queen Bees. USDA Bur Entomol Plant Quar, Bulletin ET-250

Moritz RFA, Heisler T (1992) Super and half-sister discrimination by honey bee workers (Apis mellifera L.) in a trophallactic bioassay. Insectes $S o c$ 39, 365-372

Noonan KC (1986) Recognition of queen larvae by worker honey bees (Apis mellifera). Ethology 73, 295-306

Oldroyd BP, Rinderer TE, Buco. SM (1990) Nepotism in the honey bee. Nature 346, 707-708

Oldroyd BP, Smolenski AJ, Cornuet J-M, Crozier R (1994) Anarchy in the beehive. Nature 371, 749

Page RE (1986) Sperm utilization in social insects. Annu Rev Entomol 31, 297-320

Page RE, Erickson EH (1984) Selective rearing of queens by worker honey bees: kin or nestmate recognition. Ann Entomol Soc Am 77, 578-580

Page RE, Erickson EH (1988) Reproduction by worker honey bees (Apis mellifera). Behav Ecol Sociobiol 23, 117-126

Page RE, Metcalf RA (1982) Multiple mating, sperm utilization, and social evolution. Am Nat 119 , 263-281

Page RE, Robinson GE (1990) Nepotism in the honey bee - reply, Nature 346, 708

Page RE, Robinson GE (1994) Reproductive competition in queenless honey bee colonies (Apis mellifera L). Behav Ecol Sociobiol 35, 99-107

Page RE, Robinson GE, Fondrk. MK (1989) Genetic specialists, kin recognition, and nepotism in honey-bee colonies. Nature 338, 579-579

Page RE, Breed MD, Getz WM (1990) Nepotism in the honey bee-reply. Nature 346, 707

Ratnieks FLW (1988) Reproductive harmony via mutual policing by workers in eusocial Hymenoptera. Am Nat 132, 217-236

Ratnieks FLW (1991) The evolution of genetic cue diversity in social Hymenoptera. Am Nat 137, 202-226

Ratnieks FLW (1993) Egg-laying, egg-removal, and ovary development by workers in queenright honey bee colonies. Behav Ecol Sociobiol 32 , 191-198

Ratnieks FLW (1995) Evidence for a queen-produced egg-marking pheromone and its use in worker policing in the honey bee. J Apic Res 34 , $31-37$

Ratnieks FLW, Reeve HK (1992) The structure of conflict in monogyne hymenopteran societies: processes that reduce conflict in advanced eusocial species. J Theor Biol 158, 33-65

Ratnieks FLW, Visscher PK (1989) Worker policing in the honey bee. Nature 342, 796-797

Reeve HK, Keller L (1997) Reproductive bribing and policing evolutionary mechanisms for the suppression of within-group selfishness. Am Nat 150 suppl, \$42-S58

Robinson GE, Page RE, Fondrk MK (1990) Intracolonial behavioral variation in worker oviposition, oophagy, and larval care in queenless honey bee colonies. Behav Ecol Sociobiol 26, 315-323

Sakagami SF (1954) Occurrence of an aggressive behaviour in queenless hives, with considerations on the social organization of honeybee. Insectes Soc 1, 331-343

Seeley TD (1979) Queen substance dispersal by messenger workers in honey-bee colonies. Behav Ecol Sociobiol 5, 391-415

Seeley TD (1985) Honeybee Ecology. Princeton Univ Press, Princeton, NJ

Seeley TD (1995) The Wisdom of the Hive. Harvard Univ Press, Cambridge, MA

Seeley TD, Morse RA (1976) The nest of the honey bee. Insectes Soc 23, 495-512

Starr CK (1984) Sperm competition, kinship, and sociality in aculeate Hymenoptera. In: Sperm Competition and the Evolution of Animal Mating Systems. Academic Press, Orlando, FL, 428-459

Taber S III (1955) Sperm distribution in the spermathecae of multiple-mated queen honey bees. $J$ Econ Entomol 48, 522-525

Thorley J (1774) An Inquiry into Nature, Order, and Government of Bees, those Instructive and Useful Insects. J Johnson, London

Trivers RL, Hare H (1976) Haplodiploidy and the evolution of the social insects. Science 191, 249-263

Tucker KW (1986) Visible mutants. In: Bee Genetics and Breeding. Academic Press, Orlando, FL, 57-90

Van der Blom J (1991) Social regulation of egg-laying by queenless honeybee workers (Apis mellifera L). Behav Ecol Sociobiol 29, 34 I-346

Visscher PK (1986a) Kinship discrimination in queen rearing by honey bees (Apis mellifera). Behav Ecol Sociobiol 18, 453-460

Visscher PK (1986b) The effect of location on the acceptance of queens in honey bee colonies. $J$ Apic Res 25, 154-167 
Visscher PK (1989) A quantitative study of worker reproduction in honey bee colonies. Behav Ecol Sociobiol 25, 247-254

Visscher PK (1990) Kin recognition and nepotism in Apis mellifera. In: Social Insects in the Environment. Oxford \& IBH, New Dehli, 139-140

Visscher PK (1993) A theoretical analysis of individual interests and intracolony conflict during swarming of honey bee colonies. $J$ Theor Biol $165,191-212$

Visscher PK (1996) Reproductive conflict in honey bees: a stalemate of egg-laying and policing. Behav Ecol Sociobiol 39, 237-244
Visscher PK, Dukas R (1995) Honey bees recognize development of nestmates' ovaries. Anim Behav 49, 542-544

Wheeler WM (1911) The ant colony as organism. $J$ Morphol 22, 307-325

Winston ML (1987) The Biology of the Honey Bee. Harvard Univ Press, Cambridge, MA

Woyciechowski M (1990) Do honey bee, Apis mellifera $\mathrm{L}$ workers favour sibling eggs and larvae in queen rearing? Anim Behav 39, 1220-1222

Woyciechowski M, Lomnicki A (1987) Multiple mating of queens and the sterility of workers among eusocial Hymenoptera. J Theor Biol 128 , $317-327$ 